\title{
Clay minerals associations in palaeoweathering profiles from Central Spain: genesis and implications
}

\author{
M. DOVAL ${ }^{1, \dagger}$, R. MARTÍN-GARCÍA ${ }^{2,3, *}$ Á. LA IGLESIA ${ }^{3}$ AND \\ A. M. ALONSO-ZARZA ${ }^{2,3}$ \\ ${ }^{1}$ Departamento de Cristalografia y Mineralogía, Facultad de Ciencias Geológicas, Universidad Complutense de \\ Madrid, 28040 Madrid, Spain, ${ }^{2}$ Departamento de Petrología y Geoquímica, Facultad de Ciencias Geológicas, \\ Universidad Complutense de Madrid, 28040 Madrid, Spain, and ${ }^{3}$ Instituto de Geociencias (IGEO) CSIC - UCM, \\ Facultad de Ciencias Geológicas, 28040 Madrid, Spain
}

(Received 7 June 2011; revised 2 November 2011; Editor: Enver Murad)

\begin{abstract}
This study examines part of the thick palaeoweathering mantle that formed on the northern area of the Spanish Central System. The study of a compound profile indicates that despite weathering processes, the primary structure of the metamorphic rocks is preserved, and is only partially lost in some intervals of the upper part of the compound profile. Macro/micromorphology, mineralogy and geochemical changes within the profiles revealed two weathering paths. In the first path, Fe-chlorite weathered to chlorite-smectite mixed-layer/smectite/kaolinite+ iron oxides. In the second path, biotite and/or muscovite weathered to kaolinite + iron oxides. The profiles show a progressive decrease, from base to top, in mica and mixed-layers and an increase in smectite and kaolinite. Thus, the profiles only comprise the lower or intermediate zones of the weathering mantle. The weathering occurred under humid climates; the lower zones of the profiles were poorly drained, whereas the topmost zones were better drained and more oxidizing. The results obtained indicate that detailed mineralogical studies are very useful to reconstruct the characteristics of the weathering mantles, and as palaeogeographic and palaeoclimatic indicators.
\end{abstract}

KeYwords: palaeoweathering profiles, Spanish Central System, smectite, mixed-layers, kaolinite, humid climates.

Thick palaeoweathering profiles are archives of long periods of time within the geological record (Thiry et al., 1999) that are often buried beneath younger sediments or form palaeosurfaces contributing to current landscapes. The global record of deep weathering profiles serves to identify specific geological periods undergoing intense weathering processes. For example, the highly weathered profiles occurring in Australia during the Tertiary

* E-mail: rmartingarcia@geo.ucm.es

$\uparrow$ Deceased

DOI: 10.1180/claymin.2012.047.1.117 have been correlated with profiles in Brazil (Vasconcelos et al., 1994; Dammer, 1995), suggesting that the humid conditions under which they developed were widespread (Thiry et al., 1999). Thus, palaeoweathering profiles are a useful tool for understanding ancient environments, the record of global changes as well as the distribution of ore minerals (Herrington et al., 2007). In southern Europe, two main periods of weathering are recorded: (1) thick weathering mantles developed on granites and metamorphic rocks of the Variscan (Hercynian) basement, whose age dates back to the Late Cretaceous-Early Tertiary, and (2) a more recent period affecting 
Pliocene to Lower Pleistocene "Raña" deposits (Molina \& Cantano, 2002).

In the northern area of the Central System of Spain, the San García profiles (Fig. 1) record the transition from the slates and schists of the Variscan basement to well-developed weathering profiles containing a variety of neoformed clay minerals. The clay mineral association includes significant amounts of mixed-layers, which have rarely been identified (Vicente et al., 1997; Deephty \& Balakrishan, 2005). Kaolinite is found in smaller amounts than usually found in weathering profiles developed under similar humid conditions, which may indicate either different formation conditions or the absence of parts of the profiles. The aim of this study was to determine the weathering paths of the different minerals as well as the vertical distribution of the clay minerals within the weathering profiles. The results will be used to infer the main weathering processes and the palaeoenvironmental conditions under which the weathering products formed.

\section{GEOLOGICAL SETTING}

The sampled profiles are located in the northernmost area of the Central System of Spain, which constitutes part of the Variscan (Hercynian) Massif (Fig. 1). A major fault separates the Central System from the adjacent Tertiary deposits of the Duero

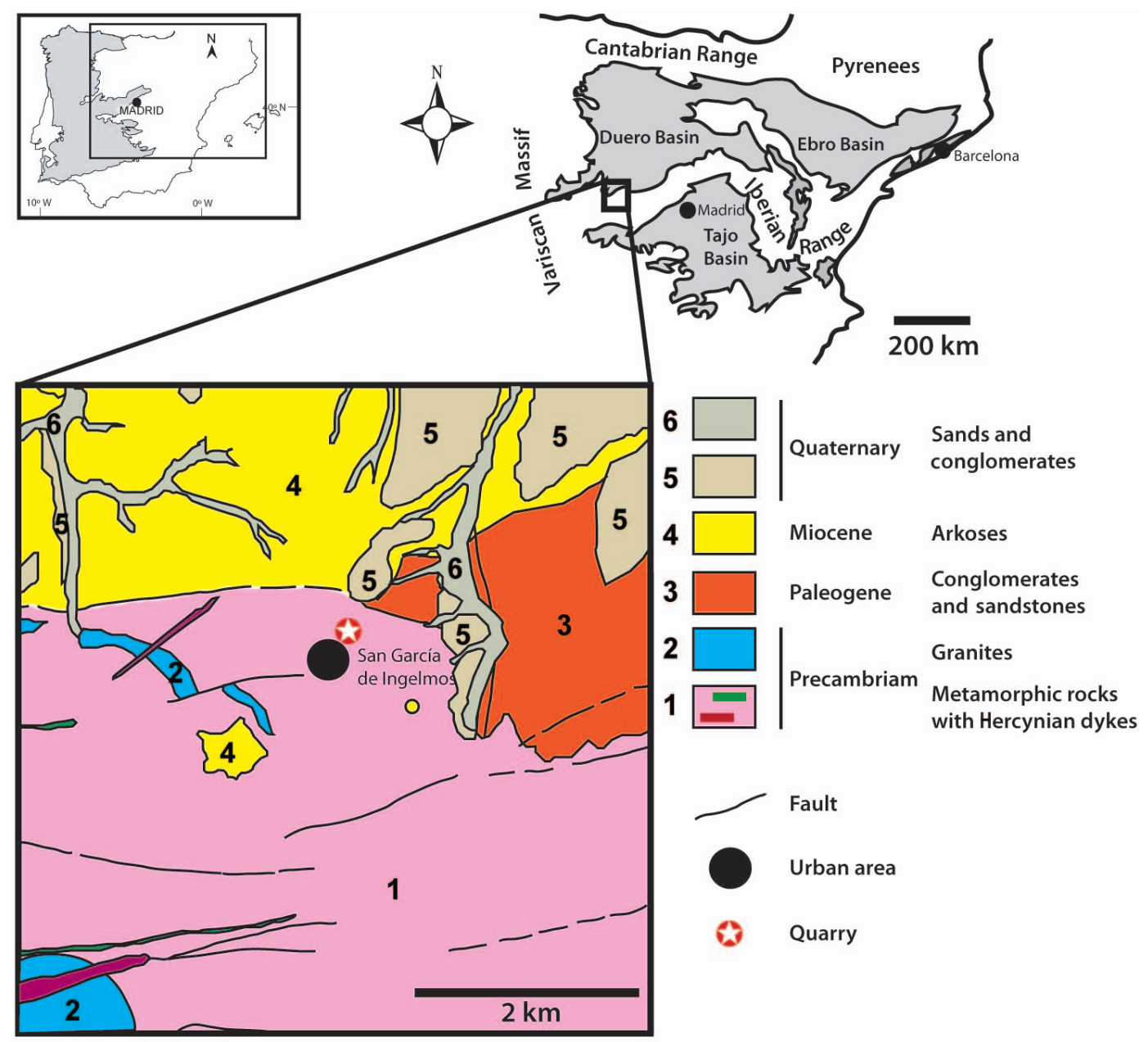

FIG. 1. Map showing the location of the study profiles in the northern area of the Central System. 
Basin (Fig. 1). In this area, the basement is composed of schists and slates with interbedded quartzites. These rocks form part of the Precambrian schist-greywacke complex (Valladares et al., 2002), which underwent regional metamorphism, leading to the formation of biotite, in some cases as large crystals, and chlorite (Fernández Carrasco et al., 1982). The main minerals present are dioctahedral mica, quartz and Fe-bearing minerals (Molina et al., 1990). The texture of the rocks is granuloblastic (Fernández Carrasco et al., 1982).

Across the entire massif, a thick weathering mantle developed on the metamorphic rocks (Molina, 2004). The mantle is either buried beneath different sedimentary covers, protected by duricrust levels (silcretes, ferricretes) (Vicente et al., 1991, 1997) or exposed on the surface. The oldest weathering profiles have been dated as being between 58 and 67 Ma (Blanco et al., 1982). However, these profiles are difficult to date and most authors argue they developed under the humid conditions prevailing from the end of the Mesozoic to Early Tertiary (Molina et al., 1990).
The study profiles are located in the northernmost part of the Central System close to the fault that separates metamorphic rocks from adjacent deposits of the Duero Basin. Where not eroded or removed by quarrying, the weathering mantle underlies Upper Tertiary red gravel deposits.

\section{MATERIALS AND METHODS}

The weathered mantle appears in a small quarry area near San García de Ingelmos in Ávila province (central Spain) (Fig. 1). The clays are exploited for use in the brick industry. Since the clays have been extensively quarried, it is difficult to obtain a single complete profile. Thus, two profiles were sampled (SG-1 and SG-2) and stacked to produce a larger compound profile. SG-1 corresponds to the lowermost part of the outcropping weathering mantle. Samples were obtained every $10 \mathrm{~cm}$ (Fig. 2). Due to their fragility, only four samples (one from the parent rock and three from the profiles) were used to prepare thin sections for petrographic studies and these same thin sections were used for microprobe studies. The samples for thin sections were vacuum-

\section{SG-1}
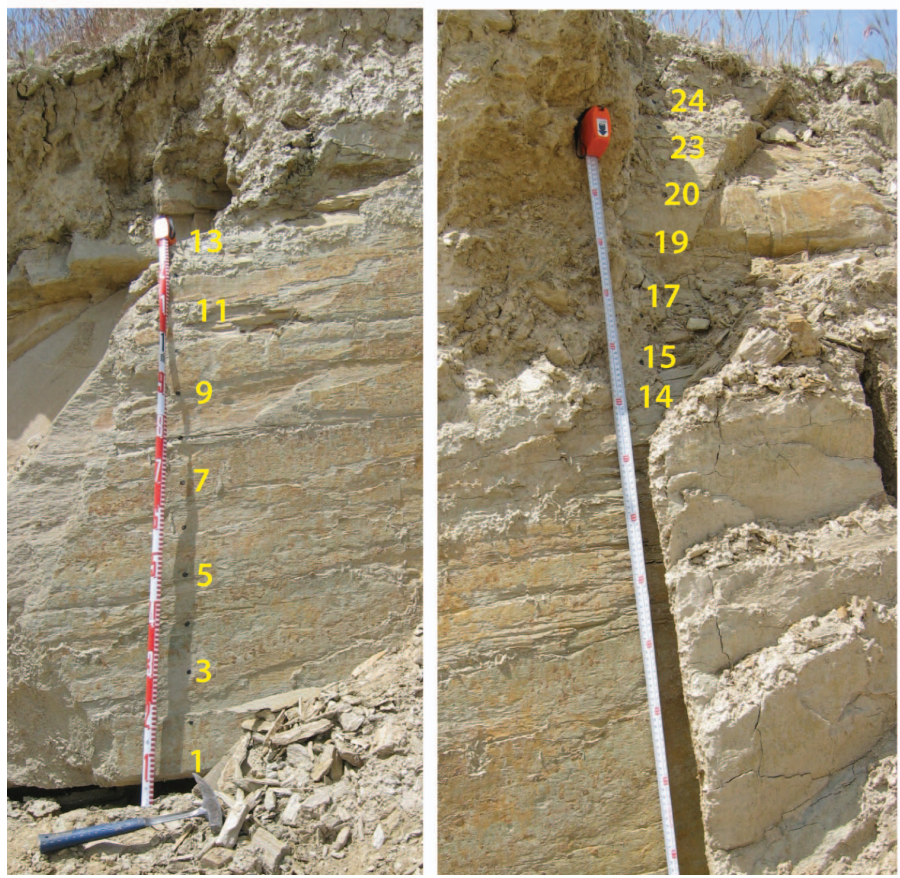

SG-2

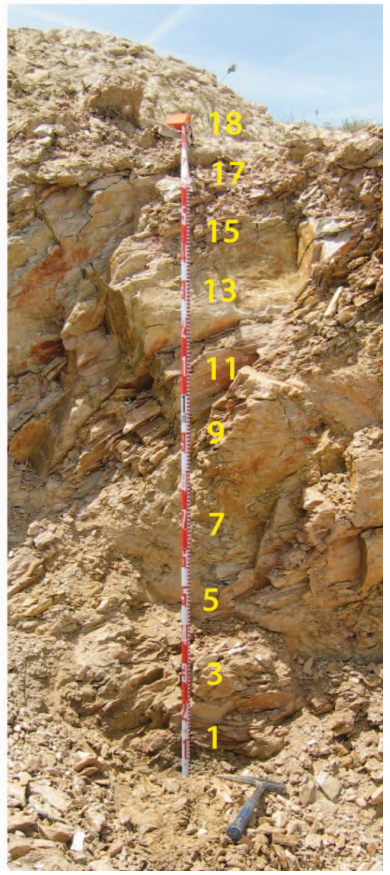

FIG. 2. Field images of the study profiles showing the location of the study samples (taken every $10 \mathrm{~cm}$ ). (A) SG-1 profile. (B) SG-2 profile. 
impregnated with a resin containing Epofer EX 401 and Epofer E 432. The mineralogical composition of the whole-rock samples was determined by X-ray diffraction using a Bruker D8 diffractometer with $\mathrm{Cu}-K \alpha$ radiation $(\lambda=1.5406 \AA$ ) equipped with a Sol-X detector recording between $2-70^{\circ} 2 \theta$. The time per step and step size were $1 \mathrm{~s}$ and $0.02^{\circ}$ respectively. The equipment operated at $40 \mathrm{kV}$ and $30 \mathrm{~mA}$. Quantitative analysis was performed by the Chung (1975) procedure using EVA software by Bruker. For clay mineralogy, $<20 \mu \mathrm{m}$ and $<2 \mu \mathrm{m}$ fractions (separated by sedimentation) were analysed using oriented air dried slides that were ethylene glycol solvated and heated at $550^{\circ} \mathrm{C}$ (Brindley, 1961). The MULCALC (Le \& Ferrell, 1996) and NEWMOD (Reynolds \& Reynolds, 1996) programs were used to characterize and quantify the clay minerals. Scanning electron microscopy (SEM) was performed with a JEOL 6.400 instrument working at $20 \mathrm{kV}$; fracture surfaces were gold coated. A wavelength dispersive electron probe microanalyser (WDS-EPMA), model JXA 8.900 (JEOL), was used to determine the proportions of the main elements within the different primary and weathering minerals.

\section{THE SAN GARCIA PROFILES (SG-1 AND SG-2)}

\section{Macromorphology}

Fresh slates do not outcrop in either profile. The two profiles show different degrees of weathering

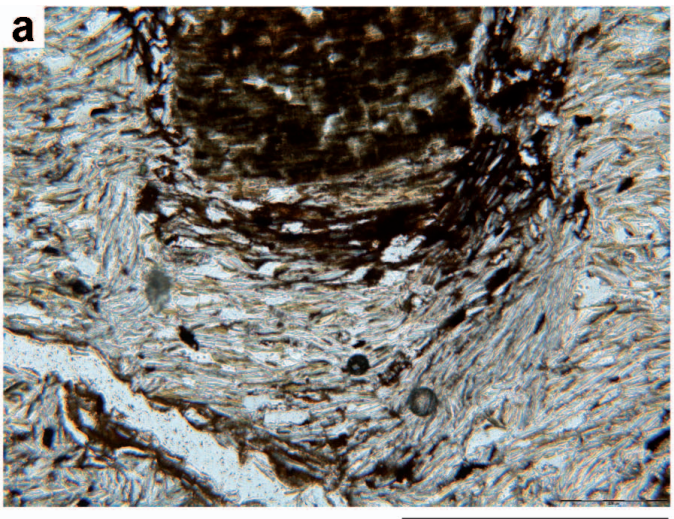

$500 \mu \mathrm{m}$

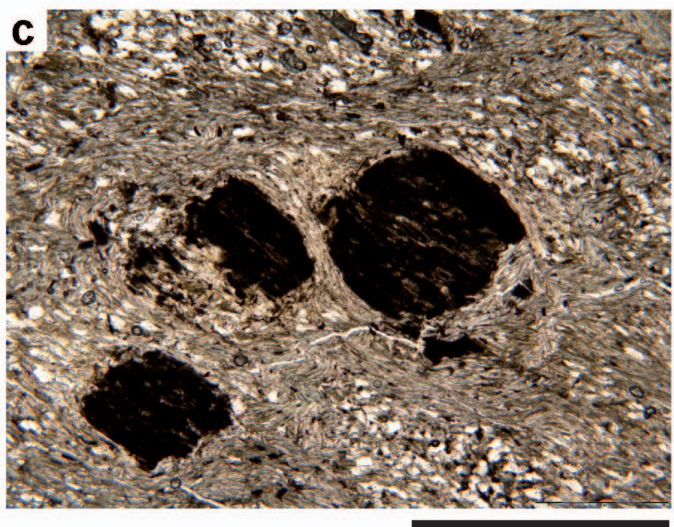

$1 \mathrm{~mm}$

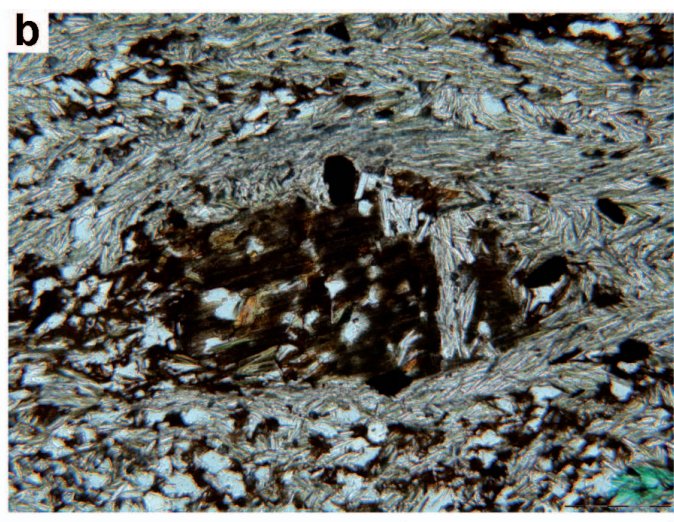

$500 \mu \mathrm{m}$

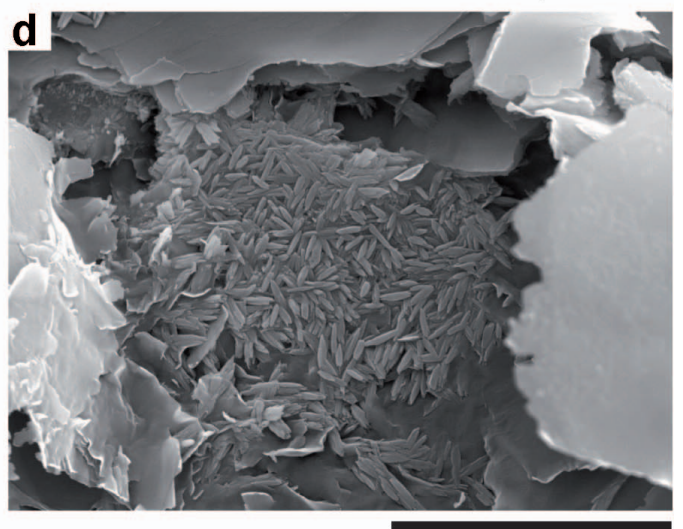

$10 \mu \mathrm{m}$

FIG. 3. (a) Micrograph showing the initial composition and structure of the metamorphic rock. Large biotite (Bt) crystal surrounded by a strongly oriented mass of mica and quartz (Mca + Qtz). (b) Disaggregation of biotite due to partial transformation into other clay mineral (CL). (c) Oxidized biotite, showing some leaching of iron, which is deposited on the biotite margins. (d) SEM image of goethite (Gt) deposited on different clay minerals. 
with SG-1 appearing less weathered than SG-2 (Fig. 2). Both developed on weathered slates, with SG-1 being situated below SG-2.

The SG-1 profile has a massive appearance and it is difficult to distinguish its different horizons. It is beige in colour (10YR 8/1), very homogeneous and $2.30 \mathrm{~m}$ thick. In the lower part $(1.20 \mathrm{~m})$, the original structure of the slates is preserved, although some fractures outline angular blocks. The upper portion $(1.10 \mathrm{~m})$ is somewhat softer and it is easy to break the weathering slates into long thin splinters.

SG-2 is $1.70 \mathrm{~m}$ thick, softer than SG-1 and homogeneous, although some diffuse banding can be discerned. The profile contains some thin fractured quartz veins. Slicken-sides occur on angular fracture surfaces. Although generally beige in colour, a few green and pale brown patches are observed. Weathering seems to be more intense in specific bands, reflecting the primary schistosity of the slates.

According to their respective macroscopic features, the SG-1 profile could represent the transition from the lower to intermediate levels, and SG-2 the intermediate levels of the weathering mantles developed on the Iberian Variscan (Hercynian) basement (Molina, 2004).

\section{Micromorphology}

The host rock consists of slates containing large biotite crystals, micronodules formed by a chloritelike mineral, quartz and different types of mica. Both biotite and micronodules appear embedded in a highly oriented mass of mica and small quartz crystals (Fig. 3a). The main weathered features observed at this scale are: partial disaggregation of the biotite margins (Fig. 3b); oxidation of the biotite to produce iron oxides (Figs 3c, d) that accumulate on their margins or appear as haloes; and expansion of the mica layers to form flakes.

\section{Mineralogy}

In both profiles, the main components are quartz, K-feldspar and clay minerals. SG-2 contains higher proportions of clay minerals and lower relative amounts of quartz, with low K-feldspar contents that do not significantly vary in the two profiles (Fig. 4), both amounts being very low. No significant differences were detected in $d_{060}$ spacings from $1.490 \AA$ to $1.538 \AA$ (Moore \& Reynolds, 1997) between the two profiles, indi- cating the probable presence of dioctahedral and trioctahedral phyllosilicates in both SG-1 and SG-2.

Oriented air dried slides revealed the presence of micaceous minerals, smectite and kaolinite in all samples (Fig. 5), though the SG-1 samples also contain a mixed-layer mineral, identified by an
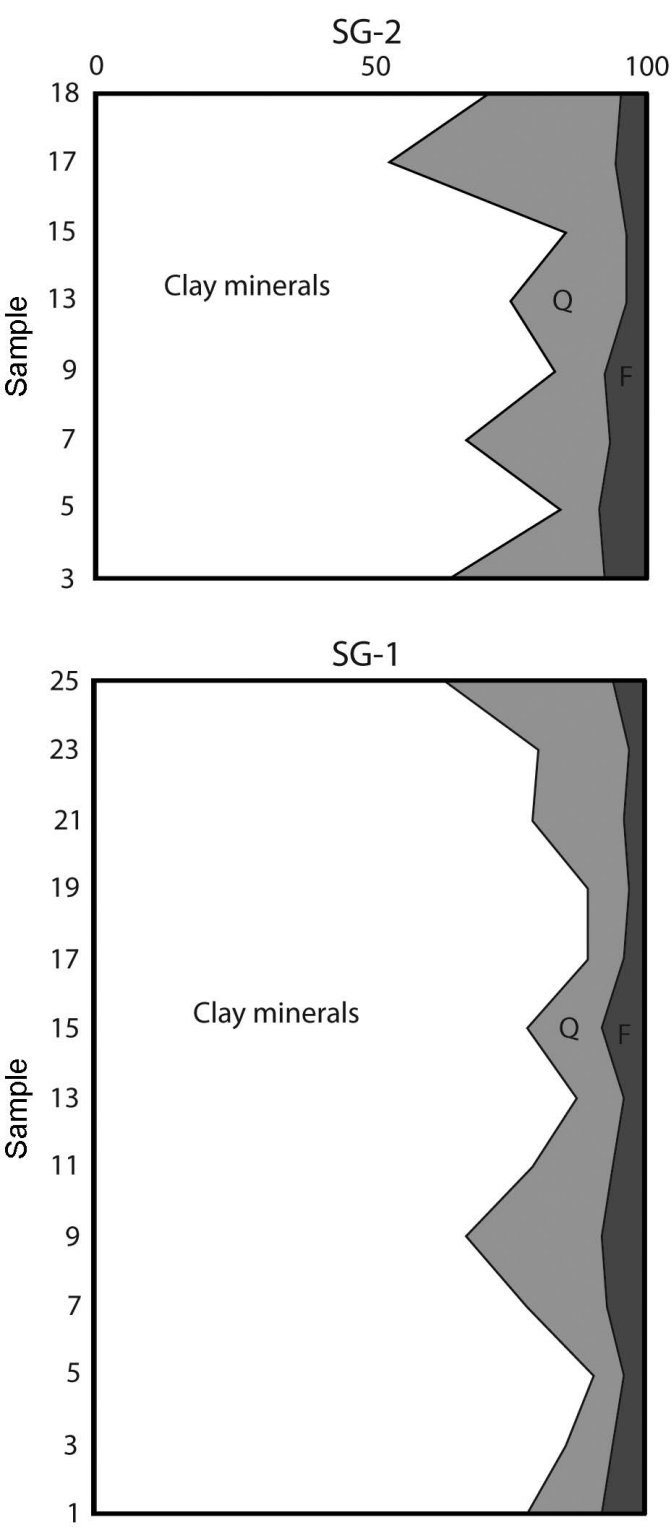

Weight (\%)

FIG. 4. Mineralogy of the profiles (SG-1 and SG-2) obtained through XRD of whole-rock samples. $\mathrm{Q}=$ quartz; $\mathrm{F}=$ feldspar 

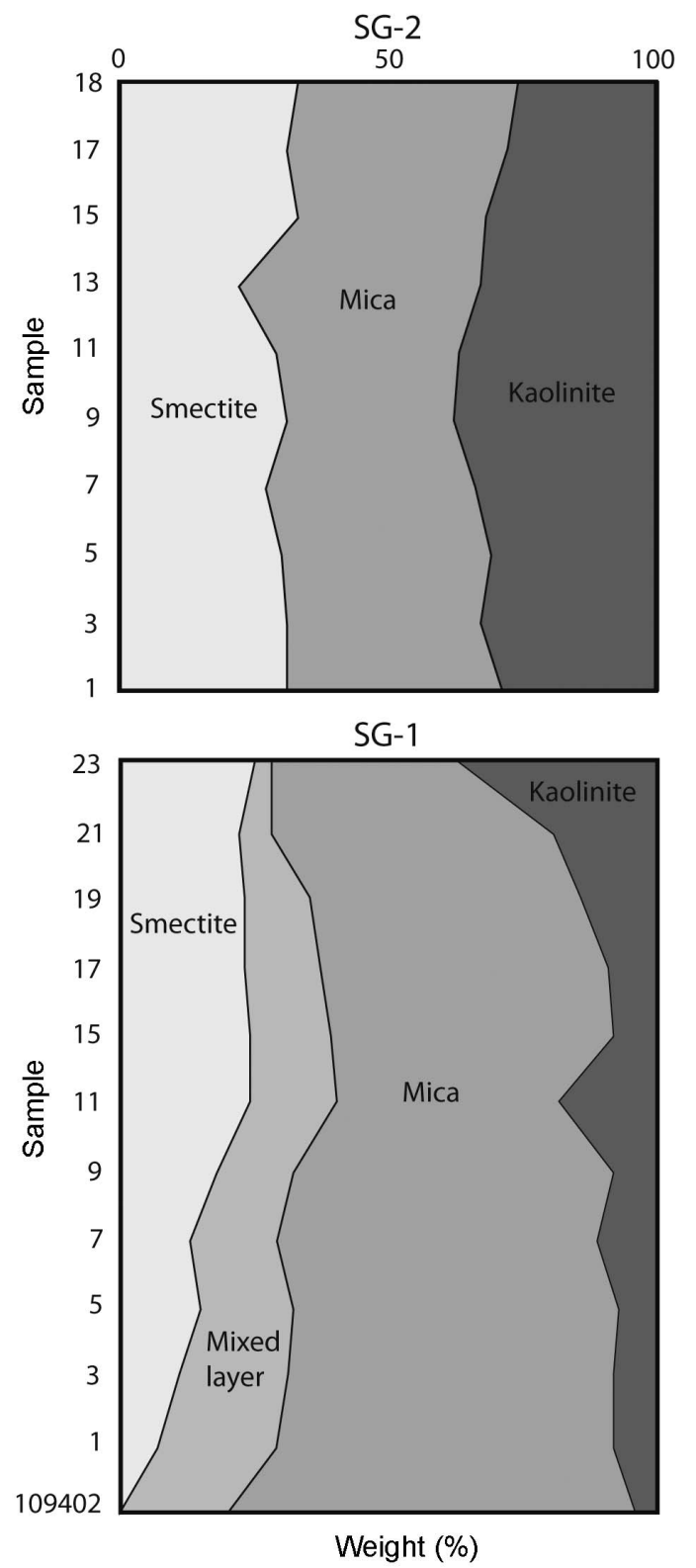

FIG. 5. Mineralogy of the $<20 \mu \mathrm{m}$ fraction in the two profiles.

11.3-11.4 $\AA$ reflection detected in the heated oriented slide $\left(550^{\circ}\right)$ and a widening of the base of the smectite peak (16.4-16.5 $\AA$ ), in the ethylene glycol solvated slides (Fig. 6). The MULCALC program indicates that these reflections are consistent with those of a mixed-layer trichlorite-(FeSil
$=1, \mathrm{Fe}$ for hydroxide $=1$ and hydroxide layer $=1$ ) trismectite $(\mathrm{Fe}=0.1)$ with $\mathrm{PA}=0.3$ and $\mathrm{R}=1$. The presence of this mineral gradually decreases upwards in the SG-1 profile and disappears at its top (Fig. 7).

Figure 5 shows the mineralogy of the $<20 \mu \mathrm{m}$ fraction of the two profiles. Mica is the main sheetmineral in both profiles, with mean contents of 54\% in SG-1 and $38 \%$ in SG-2. In contrast, SG-2 contains more smectite (30\% vs. 22\%) (Fig. 8a) and kaolinite (28\% vs. $10 \%$ ) (Fig. 8 b). The trichloritetrismectite mixed-layer is absent in SG-2, while SG-1 contains $5-25 \%$ of mixed-layers (Fig. 8c).

Variations in clay mineral contents were also appreciable when comparing the data obtained from the $<20 \mu \mathrm{m}$ fraction with those of the $<2 \mu \mathrm{m}$ fraction. For example, in two samples taken from the base and top of SG-1 (samples 3 and 21), it is clear that mica and mixed-layers occur in larger amounts in the $<20 \mu \mathrm{m}$ fraction, while the smectite content of the $<2 \mu \mathrm{m}$ fraction was notably greater than that of the $<20 \mu \mathrm{m}$ fraction.

\section{Mineral chemistry}

Microprobe analysis was used to ascertain the chemical composition of the minerals. Both the large crystals and the fine surrounding matrix were selected for analysis. The data are represented in a Velde (1973) diagram (Fig. 9). The analyses of the samples are grouped in four areas of the diagram (Fig. 9): (1) the region close to kaolinite, (2) muscovite, (3) biotite and (4) the region inside the triangle formed by a large area which includes mixed-layer minerals. Within area (4), two zones can be distinguished: zone (4a) corresponding to trioctahedral chlorite-smectite mixed-layers, and zone (4b) corresponding to dioctahedral illitesmectite mixed-layers. Differences between the samples were also noted; for instance, samples from the SG-2 profile were richer in kaolinite than the slate or samples from SG-1.

The chlorite-like mineral observed under the polarizing microscope actually corresponds, according to chemical analyses, to trioctahedral mixed-layers which may indicate that chlorites were pseudomorphic mixed-layers (Wilson, 2004) after chlorite. Both muscovite and biotite are situated in mixed-layer areas (either di- or trioctahedral) of the triangle (Fig. 9), suggesting that both micas were partially altered to smectite, although much less altered than chlorite. The transformation of clay 


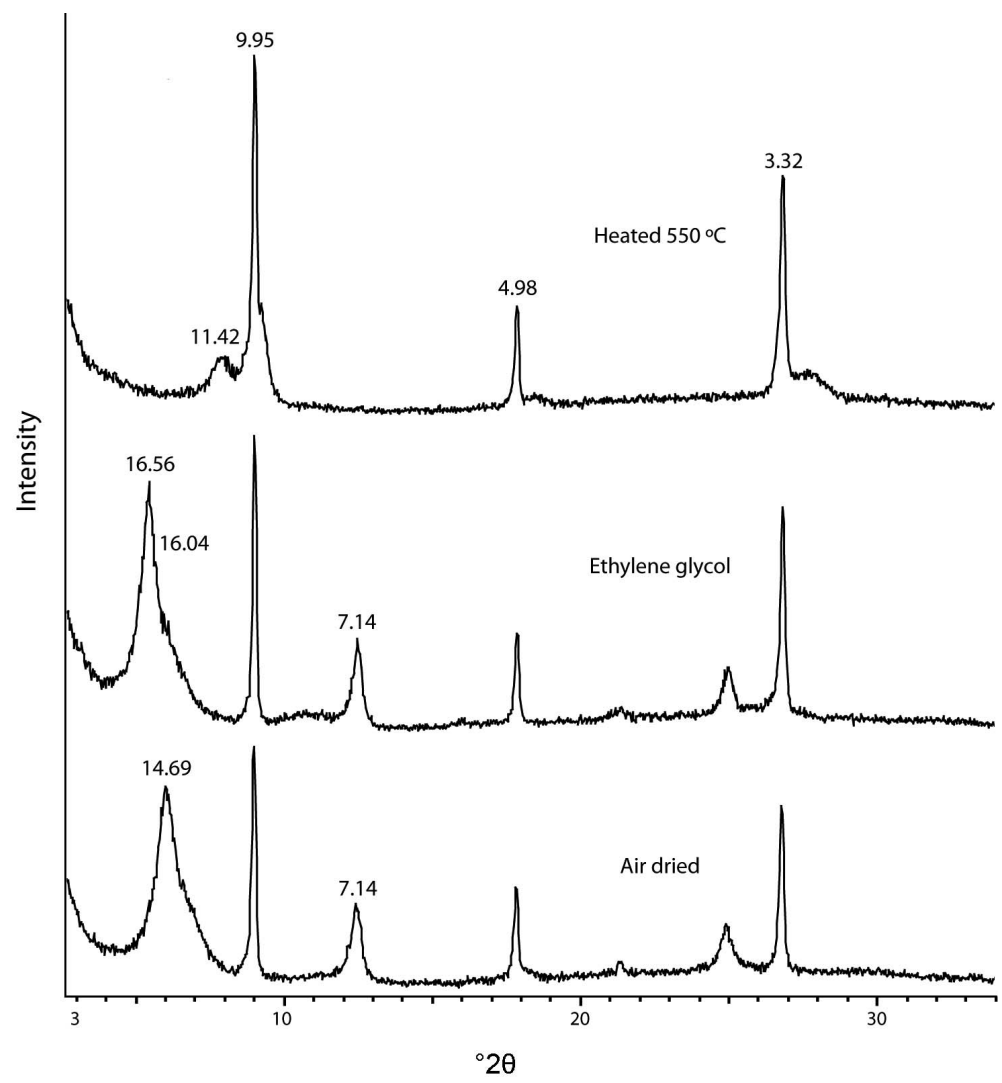

FIG. 6. X-ray diffraction patterns of the oriented sample SG-1-11.

minerals by weathering processes can be better appreciated in the microprobe images and by chemical analysis of different points within the minerals (Fig. 10a, b). Figure 10a shows that an original muscovite crystal (points 1 and 2) appears to include a dioctahedral mixed-layer (point 3 ) and there is also a trioctahedral mixed-layer present (points 4 and 5). Biotite transformation can be seen in Fig. 10b, in which points 1 and 2 are the original biotite, point 3 corresponds to a trioctahedral mixed-layer, and point 4 to an area rich in iron oxides. Areas 3 and 4 appear paler in colour.

\section{DISCUSSION}

This study has revealed that weathering processes mainly affect specific primary minerals, mostly phyllosilicates, and that there are important mineralogical variations along the profiles. Both are discussed below.

\section{Weathering trends of the clay minerals}

The weathering includes two different pathways, which start from primary minerals of the slates, being either $\mathrm{Fe}$-chlorite or mica:

(1) Fe-chlorite/chlorite-smectite mixed-layer/ smectite/kaolinite + iron oxides.

(2) Biotite and/or muscovite/kaolinite + iron oxides.

In addition, the pathways indicated are not fully completed since transformation into kaolinite is only partial and, in all cases, the previous features are also preserved.

Similar trends have been described in weathering profiles on granites or metamorphic rocks. Thus, Vicente et al. (1997) considered three different weathering stages. In the initial stage, a reduced degree of weathering preserves the primary mineralogy. In the intermediate stage, general evolution leads to the formation of smectite accompanied by an increase in silica. In the final 


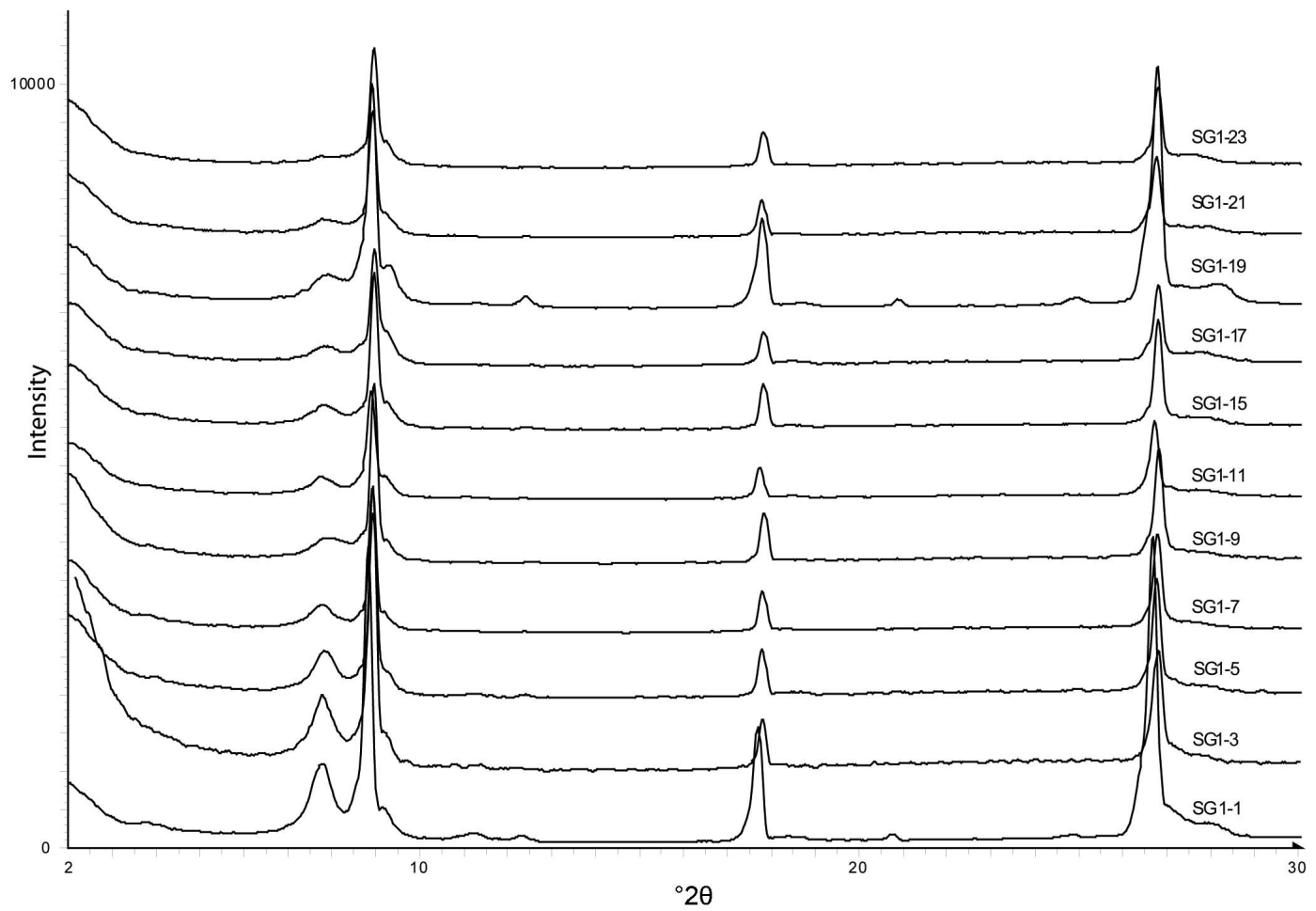

FIG. 7. X-ray diffraction patterns after heating to $550^{\circ} \mathrm{C}$ of oriented samples of profile SG-1 showing the gradual loss of reflection corresponding to chlorite-smectite mixed-layer towards the top of the profile.

stage, desilicification gives rise to the formation of kaolinite. In the last two stages, iron may remain within the profile. It is generally accepted that kaolinite forms after smectite under humid climates, (with rainfall around $2000 \mathrm{~mm} / \mathrm{yr}$ ) and that its formation takes a long period of time (more than $100 \mathrm{ka}$ ) (Bronger, 2007). In some cases, a kaolinite-smectite mixed-layer mineral can be preserved, as in some profiles in southern India (Deepthy \& Balakrishnan, 2005). Other mixedlayers, such as biotite-vermiculite profiles (not found in this study) seem to be a fleeting intermediate phase (Jolicoeur et al., 2000). This has also been observed in granite saprolites from Galicia (Taboada \& García, 1999), in which the weathering of biotite and muscovite allows the formation of the mixed-layer and iron oxyhydroxides. The presence of the chlorite-smectite mixed-layer in SG-1 is the only datum indicating the presence of chlorite as an initial mineral, which underwent weathering and is not preserved in the profiles. This mixed layer has been rarely cited (Wilson, 1999; Galán, 2006) and its origin is not clear. It could have formed through alteration of the chlorite prior to weathering or during weathering. However, the distribution of the mixed-layer along the SG-1 profile and its absence in SG-2 suggests that it formed during weathering as an intermediate phase between chlorite and smectite.

\section{Distribution of the clay minerals along the profiles}

The SG-1 profile corresponds to the lower layer of the weathering mantle which shows incipient weathering processes reflected in the preservation of the primary structures of the rock and mostly of the mineralogy. The preservation of important amounts of mica, the scarce amounts of kaolinite, and the occurrence of the chlorite-smectite mixedlayer are indicative of not very intense weathering processes. Some studies have indicated the instability of this mixed-layer even in incipient weathering processes (Begonha \& Sequeira Braga, 2002). However, the steady decrease of the mixedlayer upwards results in greater amounts of 

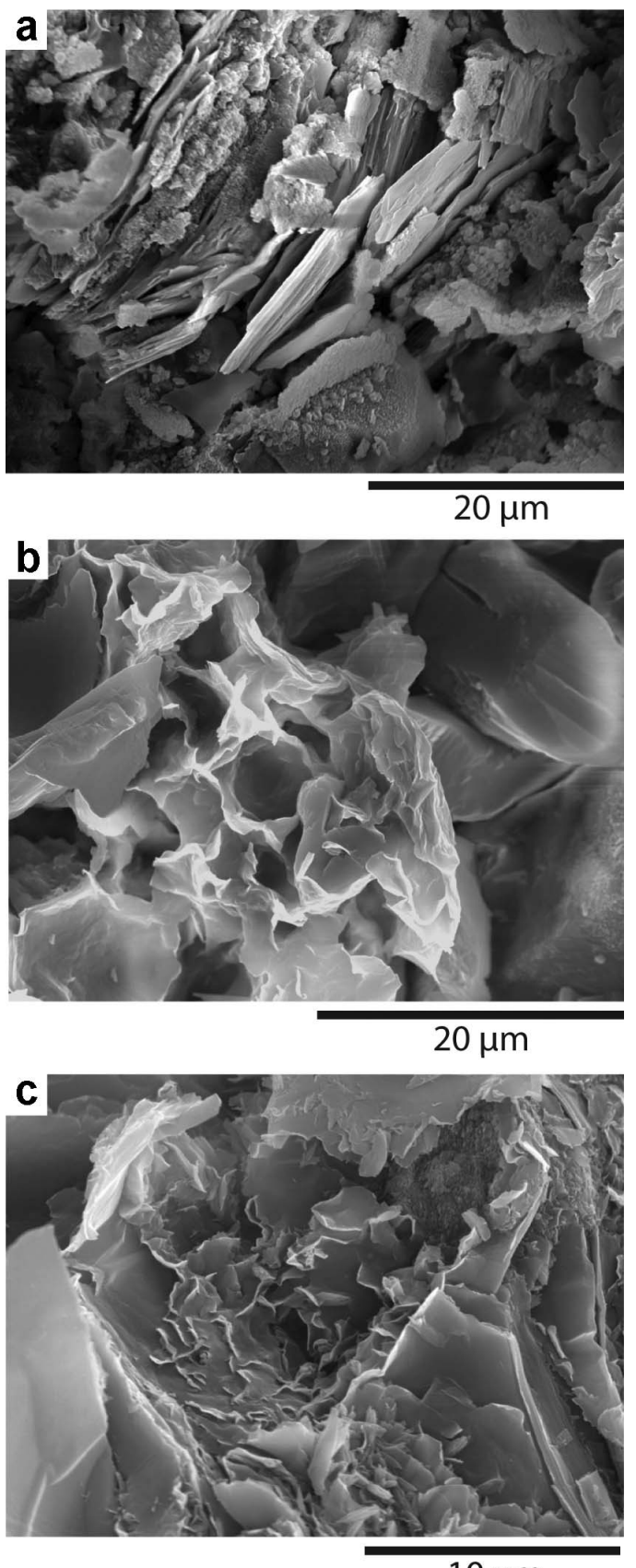

$10 \mu \mathrm{m}$

FIG. 8. SEM images. (a) Kaolinite flakes showing thin coatings of goethite (SG-2). (b) Honeycomb smectites

(SG-2). (c) Mixed-layers developed on biotites.

smectite, which are more abundant in SG-2. The higher degree of weathering in SG-2 is indicated by the loss of the mixed-layer and increasing amounts of smectite and kaolinite at the expense of chlorite and micas, respectively. Similar trends have been found in weathering mantles developed on slates in the Iberian Massif. Molina (2004) indicated that the weathering of the slates could take place in two possible geochemical environments. At intermediate zones in the profile, drainage conditions are poor and solutions move slowly, so the leached elements and silica react in nearby microsystems to form new minerals, in this case the mixed-layer or smectite. In the upper zones, drainage is more active and conditions more oxidizing, so more mobile elements are leached. In this setting, kaolinite and oxyhydroxides could form. In the study case, the higher degree of weathering was not recognized, which would correspond to the uppermost part of the profiles. This zone is characterized by a large amount of kaolinite and would show more mottling. The vertical mineralogical trends of these profiles, together with the fact that most profiles developed on slates of the Iberian Massif preserve the topmost horizons, indicate that the topmost horizon of the SG-2 profile was eroded before sedimentation of the Tertiary cover.

\section{Palaeoclimatic and paleogeographical implications}

The final mineralogy of a weathering profile depends on three main factors: the host rock, the climate and the rock drainage (Tardy, 1997). Under very humid climates, it seems that the effects of host-rock and the drainage can be ignored and the final products will be kaolinite and gibbsite (Deepthy \& Balakrishnan, 2005). In less humid climates, or less open systems, gibbsite will not form and kaolinite will form preferably at the expense of feldspars (Tardy, 1997). This study has shown that kaolinite can form at the expense of micas and chlorite and not only feldspar. The climatic conditions are difficult to pinpoint but a warm and humid climate (rainfall $>2000 \mathrm{~mm} / \mathrm{y}$ ) appears to be favourable for the formation of the weathering profiles that formed in central and northern Europe since the Mesozoic (Migon \& Lidmar-Bergström, 2001) and more specifically in the weathering mantle developed in central Spain during late Cretaceous to early Tertiary (Molina et al., 1990; Molina, 2004).

The combined results of this study (micromacromorphology, mineralogy and geochemistry) 


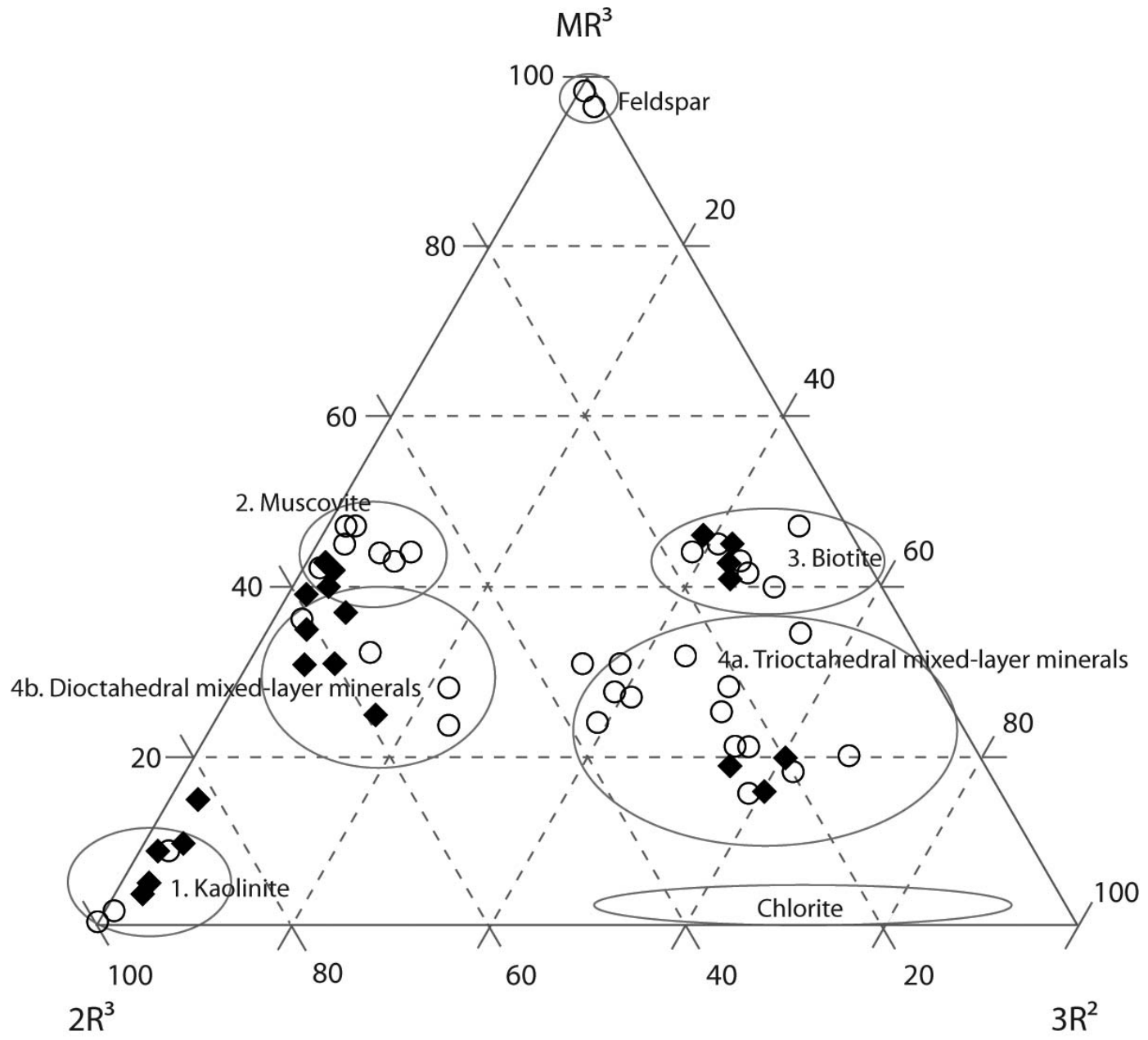

Fig. 9. Clay mineral compositions plotted on the Velde (1973) diagram and the resulting grouping. Open circles and black diamonds refer to SG-1 and SG-2 respectively. The elements are assigned to three groups: (a) divalent transition elements, including $\mathrm{Mg}$, are represented by vertex $3 \mathrm{R}^{2}$; (b) trivalent ions $\mathrm{Al}^{3+}$ and $\mathrm{Fe}^{3+}$ are represented by $2 \mathrm{R}^{3}$ and (c) alkaline and alkaline earth metals combined with a trivalent ion are $\mathrm{MR}^{3}$. Kaolinite is positioned on pole $2 \mathrm{R}^{3}$, chlorite between kaolinite and pole $3 \mathrm{R}^{2}$, muscovite appears near the central area between $2 \mathrm{R}^{3}$ and $\mathrm{MR}^{3}$, and feldspars appear on $\mathrm{MR}^{3}$.

indicate that both the SG-1 and SG-2 profiles correspond to the lower to intermediate zones of thicker weathering profiles developed on similar parent lithologies (Molina, 2004). It seems to be generally agreed that, despite intense weathering, this soft, light-coloured horizon in which the structure of the parent rock is commonly preserved, forms below the permanent groundwater table (Tardy, 1997). In more permeable host rocks, such as arkosic sediments, kaolinitization can also be produced in undersaturated zones as described by
Fernández-Caliani \& Cantano (2009), in the PlioPleistocene of South-West Spain. In this latter case rapid downward drainage and a low water table were responsible for the formation of deep kaolinite profiles also under warm and humid climates.

Apart from the common agreement that the formation of these profiles requires humid and warm climates, thus providing valuable data for palaeoclimatic reconstructions (Fernández-Caliani \& Cantano, 2009), the development of thick weathering mantles also controls the subsequent formation and 

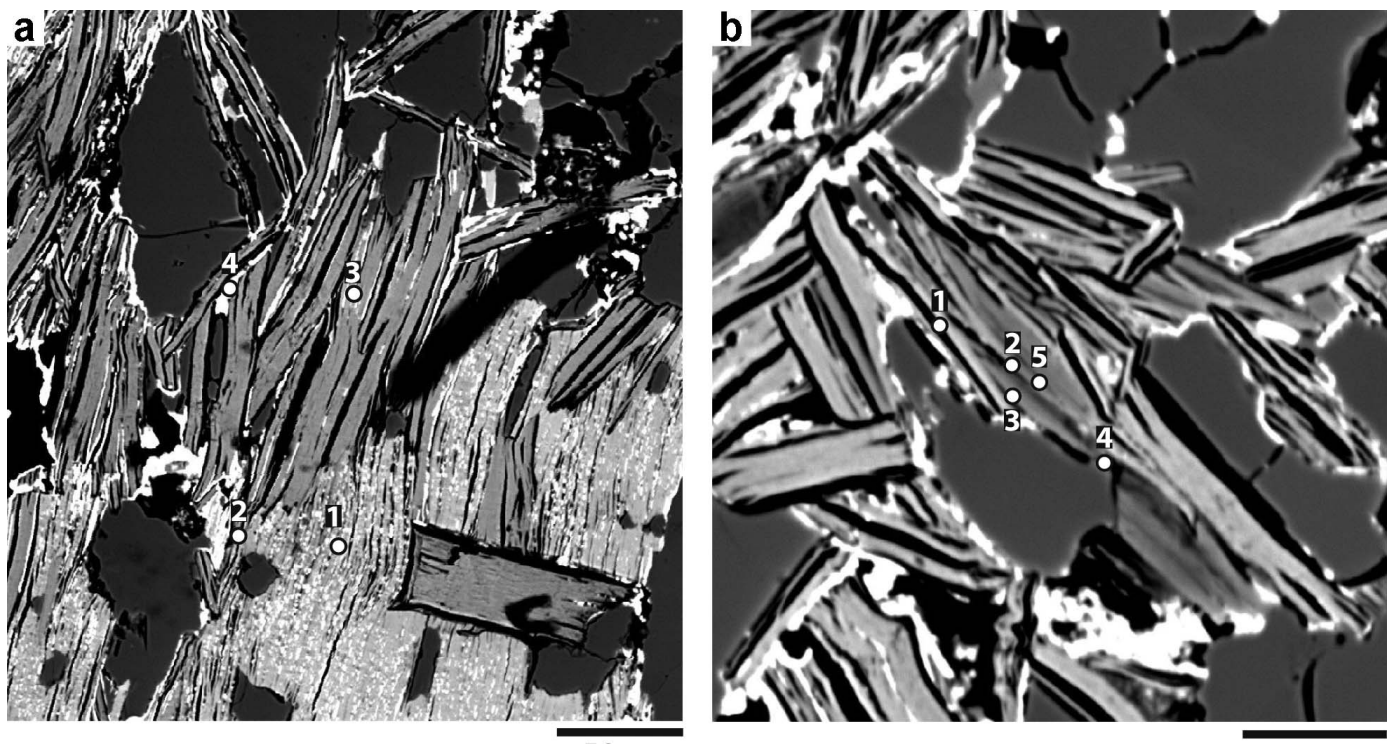

$50 \mu \mathrm{m}$

$20 \mu \mathrm{m}$

FIG. 10. Backscattered electron (BSE) microprobe images. (a) Biotite crystal undergoing weathering: $(1,2)$ Biotite; (3) Trioctahedral mixed-layer; (4) Iron oxides. (b) Compound and weathered crystal of mica: $(1,2)$ Muscovite; (3) Dioctahedral mixed-layer; $(4,5)$ Trioctahedral mixed-layer.

evolution of the landscape (Gómez-Gras \& Ferrer, 1999; Bouchard \& Jolicoeur, 2000; Twidale, 2002).

The understanding of the origin and evolution of these weathering profiles, including the determination of their completeness, and detailed geochemical data showing the weathering trends of all primary minerals are crucial to better define the palaeogeographical and palaeoclimatic conditions and their later imprint in the evolution of the landscape.

\section{CONCLUSIONS}

The study of the San García weathering profiles has focused not only on the characterization of the macro and micromorphology, but has also charted the geochemical and mineralogical weathering trends of the initial minerals. The main conclusions are:

The Fe-chlorite and micas from the host rock weathered following two different trends: (1) Fe-chlorite/chlorite-smectite mixed-layer/smectite/kaolinite + iron oxides, and (2) biotite and/or muscovite/kaolinite+ iron oxides. The final product of the weathering processes is the formation of kaolinite and iron oxides independently of the initial weathered mineral. The chlorite-smectite mixed-layers are rarely described in weathering profiles and reflect the presence of chlorite in the slates and less intense weathering processes in the lower horizons of the weathering profiles. More intense weathering processes or more humid climates will cause the transformation of the mixed-layers into smectites and/or kaolinite, which explains the rarity of mixed-layers in weathering profiles

The formation of mixed-layers and smectites could have occurred below the groundwater table, under limited drainage conditions in the lower or intermediate parts of the weathering mantle. In contrast, kaolinite formation, which is preferably occurred in profile SG-2, will indicate more active drainage and more oxidizing conditions in the intermediate or upper zones of the mantle. San García profiles do not comprise the topmost zone of the weathering mantle, in which larger amounts of kaolinite would have been expected.

The studied profiles reflect the weathering processes that affected a large zone of the Iberian Massif during the late Mesozoic to early Tertiary. The two profiles examined form part of a thick weathering mantle that developed under humid and warm conditions. Detailed geochemical studies carried out on the primary and weathered minerals 
are crucial to precisely determine the weathering trends, the characteristic features, the evolution of the weathering profiles and the palaeoclimatic conditions, even when parts of the profiles are missing.

\section{ACKNOWLEDGMENTS}

This research was financed by projects: CGL200805584-C02-02 (MCINN) and 910404 (CAM-UCM). Drs A. Pozzuoli, A. Pesce, E. Molina, E. Galán and J.C.Fernández-Caliani are thanked for the critical revision of this paper. Lorenzo Zarza is gratefully acknowledged for the selection of the study area and facilities of access. R M-G was supported by a JAE Predoc-CSIC grant. SEM and microprobe analyses were conducted at the Centro de Microscopia Luis Brú, Universidad Complutense de Madrid (Madrid, Spain).

The coauthors would like to dedicate this paper to the first author of this contribution, to our friend and colleague Mercedes Doval, who passed away leaving a deep personal and professional imprint.

\section{REFERENCES}

Begonhaa A. \& Sequeira Braga M.A. (2002) Weathering of the Oporto granite: geotechnical and physical properties. Catena, 49, 57-76.

Blanco J.A., Corrochano A., Montigny R. \& Thuizat R. (1982) Sur l'âge du debut de la sédimentation dans le bassin tertiaire du Duero (Espagne). Attribution au Palaéogéne par datation isotopique des alunites de l'Unité Inferieure. Comptes Rendues de l'Académie des Sciences, Paris, 295, 259-262.

Bouchard M. \& Jolicoeur S. (2000) Chemical weathering studies in relation to geomorphological research in southeastern Canada. Geomorphology, 32, 213-238.

Brindley G.W. (1961) Experimental methods. Pp. 1-50 in: The X-ray Identification and Crystal Structures of Clay Minerals (G. Brown, editor). Mineralogical Society, London.

Bronger A. (2007) Time dependence of the rate and direction of mineral weathering and clay mineral formation with special consideration to kaolinites. Revista Mexicana de Ciencias Geológicas, 24, 510-523.

Chung F.H. (1975) Quantitative interpretation of X-ray diffraction patterns of mixtures. III. Simultaneous determination of a set of reference intensities. Journal of Applied Crystallography, 8, 17-19.

Dammer D. (1995) Geochronology of Chemical Weathering Processes in the Northern and Western Australia Regolith. PhD thesis, Australian National University, Canberra, Australia, 214 pp.
Deepthy T. \& Balakrishnan S. (2005) Climatic control on clay mineral formation: Evidence from weathering profiles developed on either side of the Western Ghats. Journal of Earth System Science, 114, 545-556.

Fernández-Caliani J.C. \& Cantano M. (2009) Intensive kaolinitization during a lateritic weathering event in South-West Spain: Mineralogical and geochemical inferences from a relict paleosol. Catena, 80, 23-33.

Fernández Carrasco J., Olivé Davó A., Carreras Suárez F., Hernández Samaniego A., Aguilar Tomás M.J. \& Capote Villar C. (1982) Hoja geológica num. 505 (Mirueña de los Infantes). Mapa Geológico de España. E. 1: 50.000, Segunda serie, I.G.M.E., Madrid.

Galán E. (2006) Genesis of clay minerals. Pp. 1129-1162 in: Handbook of Clay Science (E. Bergaya, B. Theng \& G. Lagaly, editors). Elsevier, Amsterdam.

Gómez-Gras D. \& Ferrer C. (1999) Caracterización petrológica de perfiles de meteorización antiguos desarrollados en granitos tardihercínicos de la Cordillera Costero Catalana. Revista de la Sociedad Geológica de España, 12, 281-299.

Herrington R., Boni M., Skarpelis N. \& Large D. (2007) Palaeoclimate, weathering and ore deposits - a European perspective. Proceedings of the Ninth Biennial SGA Meeting, Dublin. Pp. 1373-1376 in: Digging Deeper (C.J. Andrew et al., editors).

Jolicoeur S. Ildefonse P. \& Bouchard M. (2000) Kaolinite and gibbsite weathering of biotite within saprolites and soils of Central Virginia. Soil Science Society of America Journal, 64, 1118-1129.

Le T.H. \& Ferrell R. (1996) MULCALC. Department of Geology and Geophysics E235 Howe/Russell Geoscience Complex, Baton Rouge, LA 70803, USA.

Migoń P. \& Lidmar-Bergström K. (2001) Weathering mantles and their significance for geomorphological evolution of central and northern Europe since the Mesozoic. Earth-Science Reviews, 56, 285-324.

Molina E.M. (2004) El papel de las alteraciones en Geomorfología: el caso de los piedemontes de relieves residuales en el zócalo Hercínico Ibérico. Pp 106-115 in: Miscelanea en homenaje a Emiliano Aguirre (E. Baquedano \& S. Rubio, editors). Museo Arqueológico Regional, Alcalá de Henares, Madrid.

Molina E. \& Cantano M. (2002) Study of weathering processes developed on old piedmont surfaces in Western Spain: new contributions to the interpretation of the "Raña" profiles. Geomorphology, 42, 279-292.

Molina E., Cantano M., Vicente M.A. \& García Rodríguez P. (1990) Some aspects of paleoweathering in the Iberian Hercynian Massif. Catena, 17, 333-346.

Moore D.M. \& Reynolds R.C. Jr. (1997) Identification 
of clay minerals and associated minerals. Pp. 227-260 in: X-ray Diffraction and the Identification and Analysis of Clay Minerals. Oxford University Press, New York.

Reynolds R.C. Jr. \& Reynolds R.C. III (1996) NEWMOD: the calculation of one dimensional Xray diffraction patterns of mixed-layered clay minerals. Computer program. R.C. Reynolds Jr., Brook Rd., Hanover 03755, New Hampshire, USA.

Taboada T. \& García C. (1999) Smectite formation produced by weathering in a coarse granite saprolite in Galicia (NW Spain). Catena, 35, 281-290.

Tardy Y. (1997) Petrology of Laterites and Tropical Soils. A.A. Balkema Publishers. Rotterdam.

Thiry M., Schmitt J.-M. \& Simon-Coinçon R. (1999) Problems, progress and future research concerning palaeoweathering and palaeosurfaces. Pp. 3-17 in: Palaeoweathering, Paleaosurfaces and Related Continental Deposits (M. Thiry \& R. SimonCoinçon, editors). IAS Special Publication, 27.

Twidale C.R. (2002) The two stage concept of landform and landscape development involving etching: origin, development and implications of an idea. EarthScience Reviews, 57, 37-74.

Valladares M.I., Ugidos J.M., Barba P. \& Colmenero J.R. (2002) Contrasting geochemical features of the Central Iberian Zone shales (Iberian Massif, Spain): implications for the evolution of Neoproterozoic-
Lower Cambrian sediments and their sources in other peri-Gondwanan areas. Tectonophysics, 352, $121-132$

Vasconcelos P.M., Renne P.R., Brimhall G.H. \& Becker, T.A. (1994) Direct dating of weathering phenomena by $40 \mathrm{Ar} / 39 \mathrm{Ar}$ and $\mathrm{K}-\mathrm{Ar}$ analysis of supergene K-Mn oxides. Geochimica et Cosmochimica Acta, 58, 1635-1665.

Velde B. (1973) Phase equilibria for dioctahedral expandable phases in sediments and sedimentary rocks. Pp 235-248 in: Proceedings International Clay Conference 1972 (J.M. Serratosa, editor), CSIC, Madrid.

Vicente M.A., Molina E. \& Espejo R. (1991) Clays in paleoweathering processes: study of a typical weathering profile in the Hercynian basement in the Montes de Toledo (Spain). Clay Minerals, 26, 81-90.

Vicente M.A., Elsass F., Molina E. \& Robert M. (1997) Paleoweathering in slates from the Iberian Hercynian Massif (Spain): investigation by TEM of clay mineral signatures. Clay Minerals, 32, 435-451.

Wilson M.J. (1999) The origin and formation of clay minerals in soils; past, present and future perspectives. Clay Minerals, 34, 7-25.

Wilson M.J. (2004) Weathering of the primary rockforming minerals: processes, products and rates. Clay Minerals, 39, 233-266. 
